\title{
As Crises Econômicas e o Segundo Império
}

\section{Resumo}

Este texto aborda aspectos da economia do Segundo Império (1840-1889) da perspectiva das crises econômicas por ele enfrentadas. De fato, as crises econômicas do Império brasileiro podem ser classificadas em duas categorias: as exógenas e as endógenas. Uma economia agroexportadora, com uma cesta reduzida em variedade de produtos ao comércio exterior sofreria efeitos cíclicos das crises do capital, à época em processo de internacionalização via Império britânico. Os próprios ciclos de produção e comercialização do café sofreriam com os desajustes cíclicos da economia internacional.

\section{Abstract}

This text deals with aspects of Brazilian economy in the Second Empire (1840-1889) in the perspective of the economic crisis faced by it. In fact, the Brazilian Empire economics crisis may be classified in two categories: the exogenous and the endogenous.

An agroexporting economy with a restricted variety of products destined to the external commerce will be subject to the capital crisis cyclical effects, in that time of internationalization process by British Empire. The cycles of coffee production and commerce would themselves suffer whith the cyclical maladjustments of the international economy.

\section{Crescimento econômico no Segun- do Reinado (1840-1889)}

A estrutura econômica do Segundo Império, que era a de uma economia agroexportadora com predomínio da cafeicultura, levou o Brasil a ocupar uma posição hegemônica no comércio internacional desse produto, no qual chegou a representar, entre 1875 e 1880, mais da metade da produção mundial. Os preços do café também se elevaram, pois o valor médio da saca passou de uma libra e 32 pence no período 1841 -1850 para duas libras e 54 pence no decênio 1881-1890. Completando os poucos espaços que o café deixava na cesta de produtos agrícolas oferecida pelo Brasil ao comércio internacional, encontravam-se culturas também crescentes de fumo, algodão, borracha e mate ${ }^{1}$. A evolução da cafeicultura e o crescimento das demais culturas podem ser vistos na tabela a seguir:

Tabela 01. Brasil, Exportação de Mercadorias: 1821-1900

\begin{tabular}{|c|c|c|c|c|c|c|c|c|c|}
\hline \multicolumn{10}{|c|}{ (\% do valor dos oito produtos principais sobre o valor total da exportação) } \\
\hline Decênio & total & café & açúcar & cacau & erva-mate & fumo & algodão & borracha & couros e peles \\
\hline $1821-1830$ & $85,8 \%$ & $18,4 \%$ & $30,1 \%$ & $0,5 \%$ & & $2,5 \%$ & $20,6 \%$ & $0,1 \%$ & $13,6 \%$ \\
\hline $1831-1840$ & $89,8 \%$ & $43,8 \%$ & $24,0 \%$ & $0,6 \%$ & $0,5 \%$ & $1,9 \%$ & $10,8 \%$ & $0,3 \%$ & $7,9 \%$ \\
\hline $1841-1850$ & $88,2 \%$ & $41,4 \%$ & $26,7 \%$ & $1,0 \%$ & $0,9 \%$ & $1,8 \%$ & $7,5 \%$ & $0,4 \%$ & $8,5 \%$ \\
\hline $1851-1860$ & $90,9 \%$ & $48,8 \%$ & $21,2 \%$ & $1,0 \%$ & $1,6 \%$ & $2,6 \%$ & $6,2 \%$ & $2,3 \%$ & $7,2 \%$ \\
\hline $1861-1870$ & $90,3 \%$ & $45,5 \%$ & $12,3 \%$ & $0,9 \%$ & $1,2 \%$ & $3,0 \%$ & $18,3 \%$ & $3,1 \%$ & $6,0 \%$ \\
\hline 1871 - 1880 & $94,9 \%$ & $56,6 \%$ & $11,6 \%$ & $1,2 \%$ & $1,5 \%$ & $3,4 \%$ & $9,5 \%$ & $5,5 \%$ & $5,6 \%$ \\
\hline $1881-1890$ & $92,3 \%$ & $61,5 \%$ & $9,9 \%$ & $1,6 \%$ & $1,2 \%$ & $2,7 \%$ & $4,2 \%$ & $8,0 \%$ & $3,2 \%$ \\
\hline $1891-1900$ & $95,6 \%$ & $64,5 \%$ & $6,0 \%$ & $1,5 \%$ & $1,3 \%$ & $2,2 \%$ & $2,7 \%$ & $15,0 \%$ & $2,4 \%$ \\
\hline
\end{tabular}

Fonte: Comércio Exterior do Brasil № 1 - C.E. e № 12-A, do Serviço de Estatística Econômica e Financeira do Ministério da Fazenda

*Mestrando em História Econômica - Faculdade de Filosofia, Letras e Ciências Humanas da Universidade de São Paulo. Bacharel em História/USP. Professor do curso de Ciências Econômicas das Faculdades Integradas "Campos Salles".

' SILVA, Hélio Schlitter. O Comércio Exterior Brasileiro no Século XIX. In: Revista de História da Economia Brasileira, 1953. 
O principal "parceiro" comercial do Brasil era a Inglaterra, seguida de longe pelos Estados Unidos. A Grã-Bretanha era responsável por absorver 32,9\% das exportações brasileiras, e fornecia $54,8 \%$ das mercadorias estrangeiras que entravam no país, em meados do século XIX. Tais números sofreriam pouco desvio ao longo do
Segundo Império. Por outro lado, a pulverização do comércio exterior com os Estados Unidos fortalecia ainda mais o poderio britânico sobre a orientação do setor dinâmico da economia brasileira, posto que o Reino Unido encampava, sem deixar sobras, o espaço deixado pelos norteamericanos, como se vê na Tabela 02:

\section{Tabela 02. Brasil: Distribuição das Importações e Exportações por país}

\begin{tabular}{|c|c|c|c|c|}
\hline \multicolumn{5}{|c|}{ (\% sobre o valor total) } \\
\hline País & \multicolumn{2}{|c|}{ Exportações para } & \multicolumn{2}{|c|}{ Importações de } \\
\hline Períodos & $1853-54 / 1857-58$ & $1870-71 / 1872-73$ & $1853-54 / 1857-58$ & $1870-71 / 1872-73$ \\
\hline Grã-Bretanha & $32,9 \%$ & $39,4 \%$ & $54,8 \%$ & $53,4 \%$ \\
\hline Estados Unidos & $28,1 \%$ & $28,8 \%$ & $12,7 \%$ & $12,2 \%$ \\
\hline França & $7,8 \%$ & $7,5 \%$ & $6,3 \%$ & $7,0 \%$ \\
\hline Alemanha (1) & $6,0 \%$ & $5,9 \%$ & $5,9 \%$ & $6,5 \%$ \\
\hline Portugal & $5,9 \%$ & $5,8 \%$ & $7,0 \%$ & $5,4 \%$ \\
\hline Bélgica & $1,8 \%$ & $1,0 \%$ & $2,0 \%$ & $2,5 \%$ \\
\hline Espanha & $0,9 \%$ & $0,8 \%$ & $1,1 \%$ & $1,6 \%$ \\
\hline Países Escandinavos & $3,7 \%$ & $0,7 \%$ & $0,4 \%$ & $0,8 \%$ \\
\hline Estados Austríacos & $1,6 \%$ & $0,0 \%$ & $0,7 \%$ & $0,2 \%$ \\
\hline Itália (2) & $1,4 \%$ & $0,5 \%$ & $0,7 \%$ & $0,5 \%$ \\
\hline Diversos & $9,9 \%$ & $9,6 \%$ & $8,8 \%$ & $9,9 \%$ \\
\hline Total & $100 \%$ & $100 \%$ & $100 \%$ & $100 \%$ \\
\hline \multicolumn{5}{|c|}{$\begin{array}{l}\text { (1) - Em 1853-54/57-58 - Cidades Hanseáticas } \\
\text { (2) - Em 1853-54/57-58 - Estados Sardos e Duas Sicílias } \\
\text { Fonte: Relatórios do Ministério da Fazenda - } 1854 \text { e } 1880\end{array}$} \\
\hline
\end{tabular}

O crescimento das exportações, sobretudo de café, passou a determinar o próprio crescimento econômico do país, ocasionando ciclos de expansão econômica qüinqüenais, vinculados ao próprio ciclo da rubiácea, onde o câmbio desempenhava papel fundamental ${ }^{2}$. Apesar dos predominantes resultados negativos no comércio exterior (Tabela 03), os resultados informa- tivos do estado da economia brasileira passaram a se dar no rescaldo de cinco anos. No qüinqüênio, de 1845-1850, houve o primeiro resultado positivo da balança comercial, que se confirmaria a partir de 1862, com exceção apenas de 1887, graças à desvalorização da moeda frente à libra esterlina, com a mudança da paridade cambial.

\section{Tabela 03. Brasil: Balança Comercial, 1833-1887}

\begin{tabular}{|l|c|c|r|}
\hline Ano & Importações & Exportações & \multicolumn{1}{|c|}{ Saldo } \\
\hline $1845-1846$ & $50.654 .827 . \$ 000$ & $53.674 .391 . \$ 000$ & $3.019 .564 . \$ 000$ \\
\hline $1846-1847$ & $55.740 .019 . \$ 000$ & $52.449 .452 . \$ 000$ & $(3.290 .567 . \$ 000)$ \\
\hline $1847-1848$ & $47.349 .641 . \$ 000$ & $57.925 .798 . \$ 000$ & $10.576 .157 . \$ 000$ \\
\hline $1848-1849$ & $51.570 .009 . \$ 000$ & $56.289 .847 . \$ 000$ & $4.719 .838 . \$ 000$ \\
\hline $1849-1850$ & $59.165 .749 . \$ 000$ & $55.289 .847 . \$ 000$ & $(3.875 .902 . \$ 000)$ \\
\hline $1850-1851$ & $79.918 .619 . \$ 000$ & $67.788 .170 . \$ 000$ & $(12.130 .449 . \$ 000)$ \\
\hline $1851-1852$ & $92.860 .415 . \$ 000$ & $66.640 .304 . \$ 000$ & $(26.220 .111 . \$ 000)$ \\
\hline
\end{tabular}

${ }^{2}$ Vide Antonio Delfim Netto, O problema do café no Brasil, capítulo I. 


\begin{tabular}{|c|c|c|c|}
\hline \multicolumn{4}{|c|}{ Tabela 03. Brasil: Balança Comercial, 1833-1887 (continuação) } \\
\hline Ano & Importações & Exportações & Saldo \\
\hline $1853-1854$ & $85.839 .336 . \$ 000$ & $76.842 .492 . \$ 000$ & $(8.996 .844 . \$ 000$ \\
\hline $1854-1855$ & $85.170 .961 . \$ 000$ & $90.698 .614 . \$ 000$ & $5.527 .653 . \$ 000$ \\
\hline $1855-1856$ & $92.779 .246 . \$ 000$ & $94.432 .478 . \$ 000$ & $1.653 .232 . \$ 000$ \\
\hline $1856-1857$ & $125.351 .935 . \$ 000$ & $114.533 .890 . \$ 000$ & $(10.818 .045 . \$ 000$ \\
\hline $1857-1858$ & $130.440 .173 . \$ 000$ & $69.247 .463 . \$ 000$ & $(61.192 .710 . \$ 000$ \\
\hline $1858-1859$ & $127.722 .619 . \$ 000$ & $106.805 .672 . \$ 000$ & $(20.916 .947 . \$ 000$ \\
\hline $1859-1860$ & $113.027 .995 . \$ 000$ & $112.957 .972 . \$ 000$ & $(70.023 . \$ 000$ \\
\hline $1860-1861$ & $123.720 .345 . \$ 000$ & $123.171 .163 . \$ 000$ & $(549.182 . \$ 000$ \\
\hline $1861-1862$ & $110.531 .189 . \$ 000$ & $120.719 .942 . \$ 000$ & $10.188 .753 . \$ 000$ \\
\hline $1862-1863$ & $99.172 .708 . \$ 000$ & $122.479 .996 . \$ 000$ & $23.307 .288 . \$ 000$ \\
\hline $1863-1864$ & $125.685 .075 . \$ 000$ & $131.151 .082 . \$ 000$ & $5.466 .007 . \$ 000$ \\
\hline $1864-1865$ & $131.746 .341 . \$ 000$ & $141.083 .446 . \$ 000$ & $9.337 .105 . \$ 000$ \\
\hline $1865-1866$ & $137.766 .842 . \$ 000$ & $157.087 .558 . \$ 000$ & $19.320 .716 . \$ 000$ \\
\hline $1866-1867$ & $145.002 .428 . \$ 000$ & $156.253 .622 . \$ 000$ & $11.251 .194 . \$ 000$ \\
\hline $1867-1868$ & $140.610 .718 . \$ 000$ & $185.370 .067 . \$ 000$ & $44.759 .349 . \$ 000$ \\
\hline $1868-1869$ & $168.510 .288 . \$ 000$ & $207.722 .633 . \$ 000$ & $39.212 .345 . \$ 000$ \\
\hline $1869-1870$ & $168.243 .703 . \$ 000$ & $197.057 .193 . \$ 000$ & $28.813 .490 . \$ 000$ \\
\hline $1870-1871$ & $144.750 .900 . \$ 000$ & $166.949 .300 . \$ 000$ & $22.198 .400 . \$ 000$ \\
\hline $1871-1872$ & $162.271 .400 . \$ 000$ & $193.418 .900 . \$ 000$ & $31.147 .500 . \$ 000$ \\
\hline $1872-1873$ & $161.419 .700 . \$ 000$ & $215.893 .100 . \$ 000$ & $54.473 .400 . \$ 000$ \\
\hline $1873-1874$ & $160.816 .000 . \$ 000$ & $190.083 .900 . \$ 000$ & $29.267 .900 . \$ 000$ \\
\hline $1874-1875$ & $160.816 .000 . \$ 000$ & $208.494 .257 . \$ 000$ & $47.678 .257 . \$ 000$ \\
\hline $1875-1876$ & $171.688 .103 . \$ 000$ & $178.880 .413 . \$ 000$ & $7.192 .310 . \$ 000$ \\
\hline $1876-1877$ & $153.886 .000 . \$ 000$ & $195.563 .800 . \$ 000$ & $41.677 .800 . \$ 000$ \\
\hline $1877-1878$ & $160.946 .400 . \$ 000$ & $187.403 .600 . \$ 000$ & $26.457 .200 . \$ 000$ \\
\hline $1878-1879$ & $162.392 .400 . \$ 000$ & $206.453 .000 . \$ 000$ & $44.060 .600 . \$ 000$ \\
\hline $1879-1880$ & $172.744 .300 . \$ 000$ & $221.928 .800 . \$ 000$ & $49.184 .500 . \$ 000$ \\
\hline $1880-1881$ & $181.005 .666 . \$ 000$ & $225.851 .718 . \$ 000$ & $44.846 .052 . \$ 000$ \\
\hline $1881-1882$ & $182.251 .691 . \$ 000$ & $209.851 .448 . \$ 000$ & $27.599 .757 . \$ 000$ \\
\hline $1882-1883$ & $190.263 .850 . \$ 000$ & $197.032 .536 . \$ 000$ & $6.768 .686 . \$ 000$ \\
\hline $1883-1884$ & $202.530 .989 . \$ 000$ & $217.072 .818 . \$ 000$ & $14.541 .829 . \$ 000$ \\
\hline $1884-1885$ & $178.431 .015 . \$ 000$ & $226.269 .654 . \$ 000$ & $47.838 .639 . \$ 000$ \\
\hline $1885-1886$ & $201.526 .356 . \$ 000$ & $191.393 .987 . \$ 000$ & $(10.132 .369 . \$ 000)$ \\
\hline $1886-1887$ & $310.850 .217 . \$ 000$ & $365.592 .152 . \$ 000$ & $54.741 .935 . \$ 000$ \\
\hline
\end{tabular}

Fonte: J. Pandiá Calógeras, A Política Monetária do Brasil.

Nesse tempo, tiveram início as estradas de ferro, a imigração estrangeira, o telégrafo, a fundação de casas bancárias, a ampliação do mercado doméstico, o crescimento de centros urbanos na região Sul do país, beneficiados pelas primeiras manufaturas, que surgiam para atender ao crescimento da economia cafeeira.

\section{Crises do capitalismo mundial: $1840-1890$}

A Europa recuperava-se das Guerras Napoleônicas, aumentando e desenvolvendo sua produção, graças a novos métodos recémdescobertos, aparecendo grandes concentrações industriais na Inglaterra, França, Alemanha, Bélgica, duplicando ou triplicando em certos casos suas populações. Os bancos difundiram-se, desempenhando papel cada vez maior no comércio interno e exterior. $O$ capitalismo rumava para a sua fase mais liberal, expandindo-se pelo globo e estabelecendo a divisão internacional do trabalho. A "pax brittanica" apresentava-se como uma nova "idade de ouro", com a difusão do livre-câmbio, eliminação das fronteiras políticas, integração das economias nacionais num sis- 
tema econômico mundial, e, como resultante, o estabelecimento de zonas de poder derivadas da supremacia britânica sobre o globo.

A marcha da indústria para o Oeste, ocorrida a partir de 1860, em busca de matérias-primas e barateamento de custos, ilustra outro lado do desenvolvimento do capitalismo naquele momento histórico. Progressivamente, a república americana deixava de ser uma exportadora de matériasprimas para se tornar uma potência industrial.

Tal crescimento não se registrou sem abalos. O século XIX também se caracterizou por crises cíclicas do capitalismo, as quais, dando-se no âmbito internacional das potências hegemônicas do hemisfério norte, afetou a conjuntura econômica reflexa e voltada para os interesses externos do Império brasileiro.

Esses abalos foram registrados na história econômica do mundo, por constituírem verdadeiros marcos divisores de épocas, por vezes com profundos reflexos sociais. Os principais e mais significativos picos de crise do capitalismo para a política econômica do Império brasileiro foram: (a) 1847-48; (b) 1857-58; (c) 1865-66; (d) 1873-74; e (e) 1885-87.

○ caráter cíclico dessas crises explica-se por um aspecto inerente ao capitalismo: a tendência decrescente da taxa de lucro ${ }^{3}$.

Em 1847, sobrevêm dificuldades nas construções ferroviárias da Inglaterra, arrastando atrás de si a construção civil, com repercussão nas indústrias mineradora e metalúrgica e conseqüente baixa da produção e dos preços. Isso acarretou crises monetárias e bancárias na Inglaterra e na França, com desemprego e depressão dos salários, o que resultou em levantes populares na
Inglaterra, com o renascimento do Cartismo, e as circunstâncias políticas de 1848, na França, Alemanha, Tcheco-eslováquia e Hungria. A abertura do mercado chinês permitiu outra fase de expansão ao capitalismo, que foi incrementada ainda pela descoberta de ouro nos Estados Unidos e na Austrália.

A superestimação das jazidas de ouro recémdescobertas, associadas à quebra de empresas ferroviárias nos EUA, Inglaterra e França, somadas à especulação imobiliária e à crise na indústria de transformação decorrentes em parte da oferta metálica, deflagraram outra crise. Nos Estados Unidos, entre 1857 e 1858, 9.655 empresas fecharam suas portas, com passivo maior do que 400 milhões de dólares.

período seguinte incensou o livre-câmbio na França e na Inglaterra, permitindo breve e tênue recuperação. Mas a Guerra Civil Americana $(1865$ - 67) causaria outra crise, que acarretaria diminuição do consumo, baixa da produção, crise monetária, crise especulativa e desemprego. Casas bancárias inglesas e francesas entraram em liquidação.

O desfecho da Guerra Franco-Prussiana, com a vitória dos germânicos, em 1870, acelerou a acumulação na Alemanha, em função das indenizações francesas de guerra. A competição pelo mercado internacional fez com que a Inglaterra expandisse as fronteiras de seu comércio internacional, forçando suas zonas de influência e colônias a adotar um rígido controle monetário, que gerava um jogo no qual, vitoriosa ou não em sua política local de controle cambial e oferta monetária, a localidade favorecia os interesses britânicos ${ }^{4}$.

\footnotetext{
${ }^{3}$ A vontade de aumentar a taxa de lucro dos capitalistas os leva a aumentar a produção, dispondo-se a aumentar a taxa real de salários dos trabalhadores. $\mathrm{O}$ aumento do lucro favorece a competição, o que acaba fazendo a produção crescer acima da necessidade do mercado. As vendas diminuem e há a queda da taxa de lucro, o que leva os capitalistas a aumentarem a composição orgânica do capital, para manter ou aumentar a taxa de lucro. Mais detalhes em Wilson Barbosa, Uma Teoria Marxista dos Ciclos Econômicos, página 4.

${ }^{4}$ Há duas hipóteses para a nação, em termos gerais: (I) a adoção rígida do padrão monetário imposto pelo lastreamento da libra e (II) o abandono desta política, cobrindo as diferenças nas transações de comércio exterior com o aumento das exportações ou o endividamento externo. No primeiro caso, cria-se uma situação de flutuações cambiais eventuais na praça local que favoreciam as transações das casas britânicas que por lá mantivessem postos. A prática mostrou que essa era uma situação insustentável e transitória, que levava à segunda hipótese comportamental.
} 
Essa nova onda de expansão britânica teve a companhia de alemães, belgas, franceses e holandeses na formação do imperialismo moderno, com a "Partilha da África" (1870 - 1914) e a disputa pela Ásia, gerando instabilidades econômicas periódicas. Em 1873, eclodem crises ferroviárias, mineiras e metalúrgicas na Alemanha, cuja queda de preços abalaria a Bolsa de Viena, produzindo pânico especulativo. Entre 1871 e 1873, mais de seis mil empresas faliram nos Estados Unidos, provocando enormes filas de desempregados.

Em 1882, verifica-se crise bolsística extremamente grave em Paris e Lyon, acontecendo a mesma coisa nos EUA, em 1884, precedida de um pânico bancário que atingiu vários estabelecimentos de crédito. O desemprego grassaria, tanto nos Estados Unidos e na França, quanto na Inglaterra, que teria índices particularmente elevados em 1887.

\section{Efeitos das crises internacionais na economia brasileira}

Esses movimentos cíclicos repetiam-se aqui de modo quase que sincronizado, de maneira automática, como se fossem seus reflexos diretos. De fato, em uma economia cujo setor dinâmico é a exportação de um produto que não possui demanda inelástica, como o café, turbulências econômicas no comércio exterior afetarão negativamente: (a) o preço da mercadoria exportada; (b) a demanda pela mercadoria exportada e (c) a disponibilidade creditícia para a produção da mercadoria exportada, bem como para as atividades ligadas a ela.

Em situação de crise econômica internacional, o preço de uma mercadoria como o café tende a baixar pela queda da procura, posta a inexistência de uma política de controle de estoques. Por outro lado, a crise deprime os mercados de oferta de crédito, fazendo com que: (a) os credores forcem os devedores já existentes a saldar mais rapidamente os seus compromissos, e (b) novos compromissos sejam tomados a taxas e prazos mais desfavoráveis para os devedores.
De toda forma, fatores internos contribuíram para o agravamento das crises econômicas do Império, a saber:

(1) A falta de meio circulante: a insuficiência de meios de pagamento na economia brasileira era crônica desde os tempos de D. Pedro I. A falta de meio circulante era tanta que as fazendas de café chegavam a imprimir seu próprio "dinheiro" em cédulas, muitas vezes com a efígie do dono, num costume herdado dos engenhos de açúcar. Mesmo admitindo-se o argumento de que em fazendas de café que utilizam mão-de-obra escrava, não há a necessidade de meio circulante impresso pelo Estado, resta a situação dos poucos centros urbanos do país, que também reclamavam da falta de moeda circulante, para o pagamento de salários, serviços e pequenas obrigações. No Segundo Império, de tempos em tempos, levantava-se a necessidade de expansão monetária, a qual, de acordo com seus defensores, traria o crescimento econômico. Alternavam-se, de acordo com os Gabinetes, as políticas de lançamento monetário. $\mathrm{O}$ que se percebe pela Tabela 04, que informa a circulação monetária do Segundo Império, são fracos movimentos de expansão, e alguns movimentos mesmo de retração da oferta de meios de pagamento, ou seja, na contramão da necessidade, retirou-se a moeda fiduciária da praça em alguns momentos da política financeira do Império.

Tal oscilação parece ser uma das poucas arestas políticas entre "conservadores" e "liberais", no exercício da política econômica imperial. Os gabinetes conservadores, compostos em sua maioria por membros que representavam os interesses da velha aristocracia latifundiária escravista, viam três "perigos" na expansão monetária: (I) a perda do controle de um mecanismo "eficiente" de manutenção dos preços do café; (II) o fortalecimento de atividades industriais, que favoreciam o trabalho livre; e (III) a mudança do ritmo da economia brasileira, o que favoreceria mudanças estruturais. Guardada a proporcionalidade, e feita a ressalva de que havia mais semelhanças e mesmo identidades entre 
conservadores e liberais, os problemas apontados pelos primeiros consistiam nas vantagens apontadas pelos setores mais radicais dos liberais: industrializar o país, mudar a estrutura agroexportadora de cesta restrita e substituir o trabalho escravo pelo livre, assalariado.

Tabela 04: Brasil, Meios de Pagamento, 1850-1888

\begin{tabular}{|c|c|c|c|}
\hline \multirow[t]{2}{*}{ Anos } & \multicolumn{3}{|c|}{ Circulação Fiduciária } \\
\hline & Tesouro & Bancos & Total \\
\hline 1850 & $46.884 .061 . \$ 000$ & $1.147 .440 . \$ 000$ & $48.031 .501 . \$ 000$ \\
\hline 1851 & $46.884 .317 . \$ 000$ & $1.313 .000 . \$ 000$ & $48.197 .317 . \$ 000$ \\
\hline 1852 & $46.884 .317 . \$ 000$ & $3.631 .050 . \$ 000$ & $50.515 .367 . \$ 000$ \\
\hline 1853 & $46.692 .805 . \$ 000$ & $5.569 .000 . \$ 000$ & $52.261 .805 . \$ 000$ \\
\hline $1853-1854$ & $46.692 .805 . \$ 000$ & $15.530 .700 . \$ 000$ & $62.223 .505 . \$ 000$ \\
\hline $1854-1855$ & $46.692 .805 . \$ 000$ & $21.062 .870 . \$ 000$ & $67.755 .675 . \$ 000$ \\
\hline $1855-1856$ & $45.692 .805 . \$ 000$ & $40.127 .970 . \$ 000$ & $85.820 .775 . \$ 000$ \\
\hline $1856-1857$ & $43.676 .895 . \$ 000$ & $51.539 .550 . \$ 000$ & $95.216 .445 . \$ 000$ \\
\hline $1857-1858$ & $41.664 .618 . \$ 000$ & $50.904 .520 . \$ 000$ & $92.569 .138 . \$ 000$ \\
\hline $1858-1859$ & $40.700 .618 . \$ 000$ & $55.172 .480 . \$ 000$ & $95.873 .098 . \$ 000$ \\
\hline 1860 & $37.599 .866 . \$ 000$ & $50.390 .980 . \$ 000$ & $87.990 .846 . \$ 000$ \\
\hline 1861 & $35.108 .373 . \$ 000$ & $46.903 .590 . \$ 000$ & $82.011 .963 . \$ 000$ \\
\hline 1862 & $33.323 .589 . \$ 000$ & $45.740 .155 . \$ 000$ & $79.063 .744 . \$ 000$ \\
\hline 1863 & $30.594 .440 . \$ 000$ & $51.126 .800 . \$ 000$ & $81.721 .240 . \$ 000$ \\
\hline 1864 & $29.094 .440 . \$ 000$ & $70.449 .315 . \$ 000$ & $99.543 .755 . \$ 000$ \\
\hline $1864-1865$ & $28.090 .940 . \$ 000$ & $72.558 .095 . \$ 000$ & $100.649 .035 . \$ 000$ \\
\hline $1865-1866$ & $28.090 .940 . \$ 000$ & $84.962 .860 . \$ 000$ & $113.053 .800 . \$ 000$ \\
\hline $1866-1867$ & $42.560 .444 . \$ 000$ & $74.600 .215 . \$ 000$ & $117.160 .659 . \$ 000$ \\
\hline $1867-1868$ & $81.749 .274 . \$ 000$ & $42.936 .935 . \$ 000$ & $124.686 .209 . \$ 000$ \\
\hline $1868-1869$ & $127.229 .722 . \$ 000$ & $55.995 .045 . \$ 000$ & $183.224 .767 . \$ 000$ \\
\hline $1869-1870$ & $149.397 .628 . \$ 000$ & $43.429 .245 . \$ 000$ & $192.826 .873 . \$ 000$ \\
\hline $1870-1871$ & $151.078 .061 . \$ 000$ & $40.727 .550 . \$ 000$ & $191.805 .611 . \$ 000$ \\
\hline $1871-1872$ & $150.806 .740 . \$ 000$ & $38.000 .000 . \$ 000$ & $188.806 .740 . \$ 000$ \\
\hline $1872-1873$ & $149.578 .732 . \$ 000$ & $35.432 .050 . \$ 000$ & $185.010 .782 . \$ 000$ \\
\hline $1873-1874$ & $149.546 .631 . \$ 000$ & $33.548 .125 . \$ 000$ & $183.094 .756 . \$ 000$ \\
\hline $1874-1875$ & $149.501 .299 . \$ 000$ & $32.367 .400 . \$ 000$ & $181.868 .699 . \$ 000$ \\
\hline $1875-1876$ & $149.379 .750 . \$ 000$ & $30.043 .075 . \$ 000$ & $179.422 .825 . \$ 000$ \\
\hline $1876-1877$ & $149.347 .859 . \$ 000$ & $30.000 .000 . \$ 000$ & $179.347 .859 . \$ 000$ \\
\hline $1877-1878$ & $181.279 .057 . \$ 000$ & $27.654 .450 . \$ 000$ & $208.933 .507 . \$ 000$ \\
\hline $1878-1879$ & $189.258 .354 . \$ 000$ & $27.654 .450 . \$ 000$ & $216.912 .804 . \$ 000$ \\
\hline $1879-1880$ & $189.199 .591 . \$ 000$ & $26.478 .225 . \$ 000$ & $215.677 .816 . \$ 000$ \\
\hline $1880-1881$ & $188.155 .455 . \$ 000$ & $24.129 .150 . \$ 000$ & $212.284 .605 . \$ 000$ \\
\hline 1881 - 1882 & $188.110 .973 . \$ 000$ & $24.129 .150 . \$ 001$ & 212.240.123.\$001 \\
\hline $1882-1883$ & $188.041 .087 . \$ 000$ & $22.955 .900 . \$ 000$ & $210.996 .987 . \$ 000$ \\
\hline $1883-1884$ & $187.936 .661 . \$ 000$ & $21.689 .300 . \$ 000$ & $209.625 .961 . \$ 000$ \\
\hline $1884-1885$ & $187.343 .725 . \$ 000$ & $20.517 .725 . \$ 000$ & $207.861 .450 . \$ 000$ \\
\hline $1885-1886$ & $194.282 .585 . \$ 000$ & $19.300 .000 . \$ 000$ & $213.582 .585 . \$ 000$ \\
\hline $1886-1887$ & $184.335 .294 . \$ 000$ & $17.956 .375 . \$ 000$ & $202.291 .669 . \$ 000$ \\
\hline $1887-1888$ & $188.869 .263 . \$ 000$ & $16.419 .100 . \$ 000$ & $205.288 .363 . \$ 000$ \\
\hline
\end{tabular}


(2) A tibieza das políticas industrializantes: os surtos industriais ocorridos nas décadas de 1850 e 1870 não tiveram expressividade suficiente para engendrar um processo industrial efetivo no país, pelas mais distintas causas ${ }^{5}$. De fato, as manufaturas fluminenses da segunda metade do século XIX sobreviveram dos efeitos conjunturais da Tarifa Alves Branco, ou das necessidades da economia cafeeira.

(3) A insipiência das proto-políticas de desenvolvimento: o Segundo Império tende a ser associado no imaginário da História do Brasil com inovações tecnológicas, como ferrovias, telefones, telégrafos etc. A evidência de contato do Império com aquelas tecnologias pode causar a idéia errada de seu uso comum e difundido. $\mathrm{Na}$ verdade, tirante a expansão da malha ferroviária, o uso de novas tecnologias não foi difundido de maneira a promover o desenvolvimento da economia brasileira, e mesmo o aumento do número de ferrovias serviu apenas à reprodução e ao incremento da exportação de café.

E, por último, em ordem de explicação, mas em primeiro no impacto da economia brasileira,

(4) A crise do trabalho escravo e sua substituição pelo trabalho assalariado: as pressões para o abandono do uso de mão-de-obra escrava exercidas sobretudo pela Grã-Bretanha desde o início do século, tornaram-se efetivas a partir de 1845, com o ultimato do Bill Aberdeen. Contudo, a resistência passiva empreendida pela elite brasileira em abandonar o escravismo refletiu-se na conhecida política gradualista, em que se buscava eliminar a escravidão em ritmo que permitisse aos latifundiários a absorção de mão-deobra assalariada, sobretudo imigrante européia. Assim, as liberdades concedidas à massa escrava vinham a conta-gotas, o que, contrariamente aos aparentes objetivos iniciais da Monarquia, que eram evitar sobressaltos políticos e manter a base de apoio ao Governo, terminaram por explicitar o vínculo fraternal da escravidão com a monarquia, indispor o Trono com sua base de apoio mais significativa, qual fosse os latifundiários escravistas cafeicultores, e atrasar o desenvolvimento econômico do país, retardando o advento dos pressupostos para a existência de um capitalismo industrial, através da existência de uma massa significativa de trabalhadores assalariados, que complementasse a existência de uma classe interessada em mais-valia ${ }^{6}$.

A crise de 1847 atingiu as exportações, forçando não só a queda da quantidade exportada, mas também o preço por unidade. $\mathrm{O}$ valor das exportações em 1848-49 seria 3\% inferior ao do período $1847-48$, e o período $1849-50$ seria ainda pior, com um decréscimo de $2 \%$ em relação ao período anterior. $\bigcirc$ caráter mundial da crise deprimiu também as importações brasileiras, sendo que, de um saldo negativo de 3.290.267 contos de réis em 1846-47, o Brasil conseguiu um superávit de comércio exterior em 1847-48 de mais de 10 mil contos de réis, devido à queda nas importações, situação mantida no ano seguinte ${ }^{7}$, e só revertida em 1850. O comportamento do câmbio indica a ação do Império. Houve a mudança da paridade pence/réis, ajustando a taxa mantida de 67,5 pence/réis, para 27 pence/réis, em 1847. Essa mudança de paridade escondeu uma grande desvalorização da moeda brasileira, feita com o intuito de manter os preços do café. O déficit na balança comercial, evidentemente, não seria de responsabilidade dos fazendeiros do Vale do Paraíba ou do Oeste Paulista. Na tabela 05 vemos as taxas máximas e mínimas de câmbio entre 1841 e 1851:

\footnotetext{
${ }^{5}$ Mais detalhes em: SOUZA, Luiz Eduardo Simões de. A Indústria brasileira nasceu grande? In: Revista Controversa. FEA/USP, n. 20, abr. 2000 .

${ }^{6}$ Leia mais em: BARBOSA, Wilson do Nascimento. A Crisálida: aspectos histórico-econômicos da escravidão no Brasil. Tese (Livre Docência). 1994. Universidade de São Paulo, São Paulo.

${ }^{7}$ 4,719 mil contos de réis em 1848-49. Fonte: Relatórios do Ministério da Fazenda, anos selecionados.
} 
Tabela 05: Brasil, Câmbio, 1841-1851 (pence por dinheiro brasileiro)

\begin{tabular}{|l|r|r|}
\hline \multirow{2}{*}{ Ano } & \multicolumn{2}{|c|}{ Taxa } \\
\hline 1841 & Máxima & Mínima \\
\hline 1842 & 32 & 29,25 \\
\hline 1843 & 29,25 & 24,5 \\
\hline 1844 & 26 & 24,75 \\
\hline 1845 & 27 & 24,75 \\
\hline 1846 & 28,25 & 26 \\
\hline 1847 & 29 & 27 \\
\hline 1848 & 28 & 24,5 \\
\hline 1849 & 28,25 & 24,25 \\
\hline 1850 & 31 & 26,75 \\
\hline 1851 & 30,5 & 27,5 \\
\hline 0
\end{tabular}

Obs: em 1847, a paridade oficial mudou de 67,5 para 27. Fonte: J. P. Calógeras, A Política Monetária do Brasil.

Note-se que a depressão das importações também foi resultante da mudança da paridade cambial. Tais fatores, associados à Tarifa Alves Branco, parecem ter favorecido o surgimento das pequenas manufaturas fluminenses.

Em 1857, a crise européia e norte-americana repercutira de modo mais profundo. As exportações, que vinham crescendo desde $1852 \mathrm{em}$ ritmo bastante favorável, à taxa média de $7 \%$ ao ano, sofreram uma queda de $15 \%$ em relação a 1856 . Se, dessa vez, a situação cambial permaneceu estável (não compensava aos cafeicultores uma nova desvalorização, o que encareceria as importações), os déficits na balança comercial fizeram uma série qüinqüenal, e premeram por novas inversões de capital externo. Mas os tomadores de empréstimos encontrariam situação diferente nas casas ban- cárias européias. Assustados pelo fracasso da "corrida do ouro" nos EUA, e pelo insucesso das companhias ferroviárias, os credores externos, ao invés de oferecerem crédito farto e fácil, reclamaram pela realização mais imediata de antigos compromissos assumidos.

O reflexo nas casas bancárias brasileiras deuse na corrida à Alves Souto, causando um prejuízo de quinze mil contos de réis à praça, e 139 falências entre 1857 e $1858^{\circ}$. Devido à restrição de crédito, vários empreendimentos como ferrovias, estradas e serviços urbanos (luz, água, esgoto) entraram em colapso, e a capacidade empreendedora de investidores como Mauá viu, repentinamente, faltar-lhe o assoalho. Mesmo as finanças do Império tiveram de recorrer ao estratagema de mudar o início do ano fiscal de janeiro para julho ${ }^{9}$. Desta vez, a expansão da produção cafeeira e a entrada dos lucros da borracha, produzida no Norte, recuperariam a situação da balança comercial brasileira.

A crise de 1864-66, dada na Europa, colhera os EUA em plena guerra civil e o Brasil às portas da Guerra do Paraguai. A situação desta crise pareceria, a princípio, favorável para a economia brasileira: a Guerra da Secessão nos EUA diminuiria a oferta de algodão daquele país, abrindo mais espaço para o algodão maranhense. Mas, se a abertura do mercado internacional às exportações brasileiras de algodão foi superestimada - graças à produção empreendida pela Grã-Bretanha no sul asiático - não o foram as eventuais restrições de mercado ao café e às necessidades de financiamento do Império, o qual, com a Guerra do Paraguai, teve de recorrer a vultosas somas, as quais pagou fazendo uso da prerrogativa que todo governo tem quando premido pelo déficit: emitir moeda. Vejamos as emissões no período:

${ }^{8}$ LIMA, Heitor Ferreira. História do Pensamento Econômico no Brasil. São Paulo: Companhia Editora Nacional, 1976, p. 121.

${ }^{9}$ Artifício que perduraria até 1888 . 
Tabela 06: Brasil, Circulação Fiduciária, 1864-1871

\begin{tabular}{|l|r|}
\hline Anos & \multicolumn{1}{|c|}{ Tesouro } \\
\hline 1864 & $29.094 .440 . \$ 000$ \\
\hline $1864-1865$ & $28.090 .940 . \$ 000$ \\
\hline $1865-1866$ & $28.090 .940 . \$ 000$ \\
\hline $1866-1867$ & $42.560 .444 . \$ 000$ \\
\hline $1867-1868$ & $81.749 .274 . \$ 000$ \\
\hline $1868-1869$ & $127.229 .722 . \$ 000$ \\
\hline $1869-1870$ & $149.397 .628 . \$ 000$ \\
\hline $1870-1871$ & $151.078 .061 . \$ 000$ \\
\hline
\end{tabular}

Circulação Fiduciária

Fonte: J. P. Calógeras, op. cit.

Como se observa acima, a quantidade de papel-moeda emitido aumentou em 93\% no período. O papel-moeda emitido pelos bancos diminuiu, como reflexo da depressão da atividade bancária, exemplificado pela derrocada final da Casa Alves Souto em 1864, acompanhada de outros 93 estabelecimentos do ramo, que enterraram um passivo de $110 \mathrm{mil}$ contos de réis, gerando perdas estimadas entre 65 e 70 mil contos ${ }^{10}$. O Banco do Brasil prestou auxílio à praça no valor de 34 mil contos de réis, dois terços do total de letras a serem protestadas, ou seja, deixando descobertos mais de $17 \mathrm{mil} \mathrm{con-}$ tos de réis. A chamada "quebra do Souto" teria repercussões nas praças comerciais e bancárias do Rio de Janeiro, São Paulo, Pernambuco, Paraíba e Bahia, ocasionando diversas falências.

Por outro lado, a entrada do Brasil na Guerra do Paraguai forçou o Império a colocar mais de 130 mil contos de réis sob sua responsabilidade na economia ${ }^{11}$. Os efeitos sobre o câmbio foram de alívio das exportações, com leve desvalorização da moeda nacional, a qual teria seu ônus atribuído ao Governo.

As crises européia e norte-americana de 1873 afetaram, novamente, as exportações brasileiras, mas em escala menor do que as crises anteriores, em relação ao desenvolvimento do volume de comércio exterior. A estabilidade do câmbio e o nível de emprego da economia brasileira foram mantidos com a redução na quantidade de papel-moeda emitido. Finda a Guerra do Paraguai, e desinteressado que estava o Império em promover a expansão de meios de pagamento à massa de trabalhadores - agora crescente, devido à imigração européia - recolhia-se, pouco a pouco, o pouco que fora emitido. Mas a cafeicultura, devido às pressões inviabilizadoras do trabalho escravo, tinha cada vez mais dificuldade em manter o nível de atividade apresentado nos anos anteriores, recorrendo a safras cada vez maiores:

Tabela 07: Brasil, Exportação de Café 1873-1878.

\begin{tabular}{|l|r|r|}
\hline Ano & Sacos de 60 quilos & $1873=100$ \\
\hline 1873 & 2.774 .000 & 100 \\
\hline 1874 & 3.853 .000 & 139 \\
\hline 1875 & 3.407 .000 & 123 \\
\hline 1876 & 3.553 .000 & 128 \\
\hline 1877 & 3.843 .000 & 139 \\
\hline 1878 & 4.904 .000 & 177 \\
\hline
\end{tabular}

Fonte: Dir. de Est.e Fin. do Tesouro Nacional

\footnotetext{
${ }^{10}$ Relatório da Comissão encarregada de estudar a crise do mês de setembro de 1864. Rio de Janeiro, Tipografia Nacional, 1865, p. 73.

${ }^{11}$ Tratava-se de moeda emitida para saldar compromissos, portanto, não serviria ao propósito de aumentar a quantidade de meio circulante, posto que, mesmo com tal emissão, a economia brasileira ainda sofria da falta de meios de pagamento.
} 
Já para a crise iniciada em 1882, o efeito depressivo nas exportações remontaria a receita ao nível de 1877, com uma produção cafeeira próxima do dobro daquela época, o que refletia a queda nos preços do café, mesmo com a desvalorização cambial, que arbitrava o valor de 20 pence para o dinheiro brasileiro. $\mathrm{O}$ início da pressão sobre os estoques, o aumento dos "custos de produção" derivado da inserção do trabalho livre e assalariado, que, por sua vez, pressionava a oferta de meios de pagamento dada pelo Império, forçava os Gabinetes imperiais a tomarem medidas que iam contra o pensamento econômico consolidado durante décadas de crescimento reflexo, portanto inercial.

Curiosamente, os últimos quatro anos do Segundo Império apresentariam condições favoráveis para o restabelecimento das finanças governamentais. $\bigcirc$ empréstimo contraído para comprar armas e equipar o exército para a Guerra do Paraguai encontrava-se com as suas prestações pagas regularmente. A extração de látex no Norte do país apresentava-se estável, pois o projeto britânico de plantar seringueiras na Malásia só adquiriria volume suficiente para inviabilizar o negócio no Brasil durante a década de 1890. A própria economia cafeeira recuperava-se de uma safra volumosa que se dera em fase de baixa de preços. O crédito de D. Pedro nos bancos ingleses, com o pagamento regular da dívida dos "papéis do Paraguai", ainda era bom: em 1888, a Cása Rotschild emprestaria mais de 25 milhões de esterlinos ${ }^{12}$.
Contudo, a Lei Áurea desferiria o golpe mortal na Monarquia: por mais que as medidas do Gabinete Ouro Preto buscassem adaptar a economia brasileira a um padrão mais dinâmico de crescimento, não havia mais credibilidade na praça para o Trono.

Assim, as crises econômicas enfrentadas pelo Império, em seus fatos geradores de natureza endêmica ou externa, estiveram sempre ligadas a esses três fatores conclusivos:

a) Circunstâncias desfavoráveis da condição instável de país monoexportador;

b) problemas crescentes com a inviabilização gradual do uso de mão-de-obra escrava, e a resistência no reconhecimento desse processo, e, por conseguinte, da tomada de medidas de favorecimento do trabalho assalariado da parte dos políticos do Império;

c) políticas monetárias restritivas, e, quando expansivas, insuficientes.

Evidentemente, tais fatores não explicam por si os caminhos adotados pelos decisores políticos tanto do Império quanto da Primeira República (1889-1930). Contudo, parece-nos difícil apontar outros fatores exclusivamente de ordem econômica que tenham participado na consolidação ${ }^{13}$ do que, segundo Caio Prado Júnior, consiste um caráter "geral" de nossa economia: "uma organização fundada na produção de matérias-primas e gêneros alimentares demandados nos mercados internacionais". Quaisquer outros fatores passariam, em nossa visão, pela esfera política.

${ }^{12}$ CALÓGERAS, J. P. A política monetária do Brasil, p. 190-4.

${ }^{13}$ Por exemplo, gastos públicos, ou contas "avulsas" de um "balanço de pagamentos construído retroativamente", sobre o qual certo tipo de historiografia econômica se debruça. A mensuração dos gastos públicos via renda "determinada pelas exportações", no primeiro exemplo, nos parece portar certa confusão entre identidades macroeconômicas e variáveis macroeconômicas. No extremo oposto repousa o erro, em nossa opinião, do segundo exemplo: como constituir, a partir de categorias estabelecidas posteriormente como modelares em Bretton Woods, um modelo interpretativo do século XIX? 


\section{REFERÊNCIAS BIBLIOGRÁFICAS}

BARBOSA, Wilson do Nascimento. A Crisálida: aspectos histórico-econômicos da escravidão no Brasil. 1994. Tese (LivreDocência). Departamento de História, Universidade de São Paulo, São Paulo.

BARBOSA, Wilson do Nascimento. Uma Teoria Marxista dos Ciclos Econômicos, in COGGIOLA. Osvaldo. Marx e Engels na História. São Paulo: Humanitas, 1996.

CALÓGERAS, João Pandiá. A Política Monetária do Brasil. São Paulo: Companhia Editora Nacional, 1960.

FURTADO, Celso. Formação Econômica do Brasil. 9. ed. São Paulo: Companhia Editora Nacional, 1969 (1959).

HOLANDA, Sérgio Buarque de (org.). História da Civilização Brasileira. São Paulo: Bertrand, v.5 e v.7, 1984.

LIMA, Heitor Ferreira. História do Pensamento Econômico Brasileiro. Rio de Janeiro: Companhia Editora Nacional, 1976.

NETTO, Antonio Delfim, O Problema do Café no Brasil. 1955. Tese (Doutorado)- Faculdade de Economia e Administração, Universidade de São Paulo, São Paulo.

PRADO JÚNIOR, Caio, História Econômica do Brasil. São Paulo: Brasiliense, 9. ed., 1981 (1945).

Relatórios do Ministro da Fazenda, vários anos.

Revista de História da Economia Brasileira, número 1, 1953.

SOUZA, Luiz Eduardo Simões de. A Indústria Brasileira Nasceu Grande? Revista Controversa, São Paulo, n. 20, FEA-USP, abr. 2000. 